\title{
Yüksek Dereceli Glial Tümörlerin Radyoterapisinde VMAT Tekniği İle IMRT Tekniğinin Karşılaştırılması
}

\author{
Hazım Orhan Kızılkaya ${ }^{1 *}$, Yonca Yahşi Çelen ${ }^{2}$, Ayşe Okumuş ${ }^{3}$, Deniz Arslan ${ }^{4}$ \\ Sisli Hamidiye Etfal Training and Research Hospital, Department of Radiation Oncology, İstanbul-Turkey (ORCID: 0000-0001-6946-7539), orhankizilkaya959@ yahoo.com \\ ${ }^{2}$ Balıkesir University, Department of Biophysics, Balikesir- Turkey (ORCID:0000-0002-2869-664X), yoncayahsi@gmail.com \\ ${ }^{3}$ Yeni Yüzy1l University, Gaziosmanpasa Hospital, İstanbul-Turkey (ORCID: 0000-0003-4721-0534), ayseokm@ gmail.com \\ ${ }^{3}$ Yedikule Chest Diseases and Thoracic Surgery Education and Research Hospital, İstanbul-Turkey (ORCID: 0000-0003-0080-2284), denizsaracoglu@ @otmail.com
}

(Illk Geliş Tarihi 3 Eylül 2020 ve Kabul Tarihi 24 Ekim 2020)

(DOI: 10.31590/ejosat.799077)

ATIF/REFERENCE: Kızılkaya, H. O., Yahşi Çelen, Y., Okumuş A. \& Arslan, D. (2020). A Comparison of Volumetric Modulated Arc Therapy and Conventional Intensity-Modulated Radiotherapy for High Grade Glial Tumors. Avrupa Bilim ve Teknoloji Dergisi, (20), 404-408.

$\ddot{O} z$

Radyoterapide amaç, belirlenen hedef hacim üzerine en uygun dozu verirken, radyasyona hassas kritik organları ve civarındaki sağlıklı dokuları mümkün olduğunca korumaktır. Bu çalışmanın amacı, Bilgisayarlı tomografi (BT) görüntüsü alınmış 10 beyin tümörü tanılı hastanın, Eclipse tedavi planlama sisteminde VMAT tekniği kullanılarak oluşturulan en iyi planlarla, yedi alanlı IMRT tekniği kullanılarak oluşturulan en iyi planları kritik organ dozları, hedef hacim, tedavi süreleri ve monitör unit (MU) değerleri açısından karşılaştırmaktır. Çalışma retrospektif bir çalışma olup, hastalar çalışmalarda geçen plan ve tekniklerle tedavi edilmemiştir. Hedef hacim için tanımlanan dozun \%100'ü hedef hacmin en az \%95'ini alacak şekilde planlamalar yapılmışıtır. Elde edilen doz-volüm histogramları aracılığıyla çalışılan farklı planların hedef hacim ve kritik organ dozları Radiation Therapy Oncology Group (RTOG) protokolünden faydalanarak, eşleşmiş veriler için $\mathrm{t}$ - testi kullanılarak minitab programı ile alınan sonuçlar istatistiksel olarak değerlendirilmiştir. PTV kapsamı, konformite ve homojenite indeksi VMAT ve IMRT planları için eşdeğerdi. VMAT planları IMRT ile karşılaştırıldığında PTV max. $64,835 \pm 0,504(\mathrm{p}=0,039)$, Beyin max. $64,378 \pm 0,565(\mathrm{p}=0,025)$, ve Eye L. max. 20,39 $\pm 12,17 \quad(\mathrm{p}=0,046)$ için ortalama dozları arasında fark istatistiksel olarak anlamlıdır. Beyin ortalama 26,74 $\pm 3,42(\mathrm{p}=0,096)$, Beyin Sapı max. $32,44 \pm 18,70(\mathrm{p}=0,178)$, Eye $\mathrm{R}$.

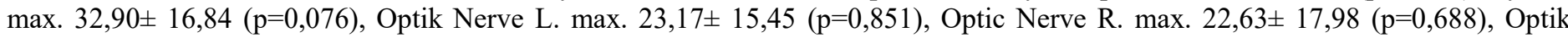
Kiazma max. 25,25 20,24 (p=0,531) dozları VMAT planlarında daha düşük bulunmasına karşılık istatistiksel olarak anlamlı değildir. VMAT tekniği ile yapılan planlarda daha az monitor unit (MU) ve daha kısa tedavi süresi olması nedeniyle tercih edilebilinir.

Anahtar Kelimeler: Beyin tümörleri, Yüksek dereceli glioma, Yoğunluk ayarlı radyasyon tedavisi(IMRT), Volumetrik modüle ark tedavisi (VMAT)

\section{A Comparison of Volumetric Modulated Arc Therapy and Conventional Intensity-Modulated Radiotherapy for High Grade Glial Tumors}

\begin{abstract}
The aim of radiotherapy is to protect critical organs sensitive to radiation and surrounding healthy tissues as much as possible, while giving the most appropriate dose on the specified target volume. The aim of this study is to provide the best plans of 10 brain tumor patients, whose computed tomography (CT) image was taken, using the best plans created using the VMAT technique in the Eclipse treatment planning system and the best plans created using the seven-field IMRT technique to compare doses in terms of target volume, duration of treatment and monitor unit (MU) values. The study is a retrospective study and patients were not treated with the plans and techniques used in the studies. Plans have been made so that $100 \%$ of the dose defined for the target volume will take at least $95 \%$ of the target volume. Using the Radiation Therapy Oncology Group (RTOG) protocol, the results obtained with the minitab program were statistically evaluated using the t-test for the matched data. PTV coverage, conformity and homogeneity index were equivalent for VMAT and IMRT plans. VMAT plans compared to IMRT, PTV max. 64,835 $\pm 0,504$ (p=0,039), Brain max. 64,378 $\pm 0,565$ (p=0,025), and Eye L. max. 20,39 $\pm 12,17(\mathrm{p}=0,046)$ The difference between the mean doses is statistically significant. Brain mean $26,74 \pm 3,42$

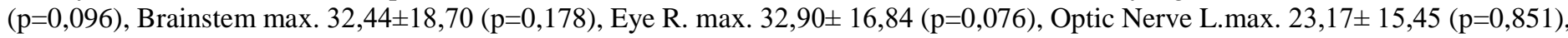

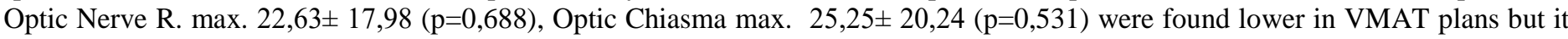

\footnotetext{
* Corresponding Author: Sisli Hamidiye Etfal Training and Research Hospital, Department of Radiation Oncology, İstanbul-Turkey, ORCID: 00000001-6946-7539, orhankizilkaya959@yahoo.com
} 
was not statistically significant. It may be preferred in plans made with the VMAT technique due to less monitor units (MU) and shorter treatment time.

Keywords: Brain tumors, High- grade glioma, Intensity- modulated radiotherapy (IMRT), Volumetric modulated arc therapy (VMAT)

\section{Introduction}

Primary brain tumors are the 6 th most common malignancy among all malignancies. $2 \%$ of cancers and $3 \%$ of deaths due to cancer occur due to brain tumors (Noone et al. 2015). Central nervous system (CNS) tumors peak between the ages of 65-84 with an increasing frequency starting from the 20 s and then decrease. Brain tumors were first described macroscopically by Cruveilhier in 1829 and classified as microscopically by Bressler in 1836. However, Wirchow laid the foundation for the current classification of brain tumors. He described neuroglia as the intercellular matrix of the brain in 1860. Again, Wirchow defined the connection between macroscopic and microscopic features of tumors and made the definition of "glioma" for the first time. Although many classification systems have been used so far, the most frequently used classification system is the World Health Organization (WHO) classification in 1993, which was revised in 2016 (Lous et al., 2016, Kleihues \& Cavenee, 2000). Today, the incidence of brain tumors is gradually increasing. Brain tumors are divided into low-grade and high-grade tumors, and more than $2 / 3$ of these tumors form glioblastoma (GBM) with a poor prognosis.

Brain tumors are divided into two groups as benign and malignant tumors. Benign tumors have a slow growth rate. In addition, they can be easily separated from the brain part and all or almost all of them can be easily removed. Malignant tumors grow very quickly. They have the consistency of mud. Therefore, not all of them can be removed surgically. After the operation, they grow again in a certain period of time and continue to put pressure on the brain (Lyman, 1985, Meral, 2007).

Glial tumors are pathologically classified into 4 groups. Grade I and II tumors, low grade; Grade III and IV tumors are high grade.

\section{Grade I: Pilocytic Astrocytoma}

Grade II: Astrocytoma, Oligodendroglioma;

Grade III: Anaplastic Oligodendroglioma, Anaplastic Astrocytoma, Anaplastic Oligoastrocytoma

\section{Grad IV: Glioblastoma Multiforme (GBM)}

With the 2016 regulation of WHO, besides the morphological diagnosis, genetic changes played a role in the diagnosis. Presence of IDH mutations or its absence affects the behavior pattern.

A pre-diagnosis is made by contrast-enhanced cranial magnetic resonance imaging (MRI) or computed tomography (CT) taken after a detailed physical and neurological examination. Histological diagnosis is made by surgical resection or by biopsy in cases that are not suitable for surgery. The diagnosis is made radiologically in optic gliomas and brainstem gliomas. Histology, tumor grade, and its negative or positive IDH are very important in planning treatment and determining prognosis (Çetingöz, 2015, Gunderson \& Tepper, 2008).

The main treatment for high-grade glial tumors is surgery, but surgery may not be possible in some cases. If the tumor is located in some very sensitive vital parts of the brain, touching these areas is life-threatening, so radiation therapy (radiotherapy) and drug therapy (chemotherapy) can be applied in this case. It is necessary to apply adjuvant radiotherapy or concomitant chemoradiotherapy to nearly eighty percent of surgically viable tumors. Tumors that occur in other parts of the body can also metastasize to the brain (Komaki et al., 1995).

With the improvement in the prognosis of high-grade gliomas with the combined use of radiotherapy and chemotherapy, the long-term survival and late radiation effects of patients are becoming more and more important. Intensity-modulated radiotherapy (IMRT) is an investigated treatment for high-grade gliomas as a way to increase the dose and reduce late toxicity. According to the results of the retrospective analysis, IMRT has been shown to reduce acute and long-term neurotoxicity compared to three-dimensional conformal radiotherapy (3DCRT) and at the same time protect progression-free and overall survival equally (Narayana et al., 2006).

When the plan studies using three-dimensional conformal radiotherapy (3D-CRT) and noncoplanar IMRT technique were compared, it was seen that IMRT technique provided dosimetric advantage for high-grade gliomas (Narayana et al., 2006, Thilman et al., 2001).

IMRT plans resulted in better coverage of the planned target volume (PTV) dose in organs at risk (OAR) while reducing the dose. In clinical studies, better dosimetry and patient outcomes were obtained with both coplanar and non-coplanar IMRT techniques (Narayana et al., 2006, Floyd et al., 2004, Miwa et al., 2008).

For high grade gliomas, if PTV intersects with optic nerve, chiasma and brainstem, 7-area coplanar can be treated with IMRT technique. Because in the IMRT technique, it is possible to wrap the dose in this PTV area, which shows less convexity compared to other parts of the brain, better than 3D-CRT.

Volumetric Modulated Arc Therapy (VMAT), first proposed by $\mathrm{Yu}$ in 1995, provides radiation therapy using overlapping arcs (Yu, 1995). Treatment plans are computer-optimized to meet dose-volume targets, such as conventional fixed-field IMRT.

\section{Material Method}

Ten patients with a diagnosis of high grade glial tumor previously treated were included in the study. Retrospectively selected patients were not treated with the plans and techniques used in the study, and our aim is to compare the dosimetrically critical organ doses and target volume maximum doses as a result of the comparison of treatment plans made with different techniques in the Varian Trilogy Linear Accelerator device treatment planning system. The plans of the patients participating in the study were rescheduled in the Varian Trilogy device Eclipse treatment planning system.

In the Eclipse treatment planning system, the treatment plans of the patients were planned using the 7-field IMRT technique $(0,38,76,114,246,284,322)$ angles and 6 MV photon energy. Treatment plans prepared using the VMAT technique were made using 2 full arc or 2 half arc technique, depending on the location of the disease. 60 Gy dose was defined in 30 fractions and the plan was studied. 
Computed tomography (CT) scanning of 10 patients in the study was achieved by making a thermoplastic mask in a position that will provide the most optimal planning convenience for each patient with a $3 \mathrm{~mm}$ cross-section range and keeping the head fixed. While the contouring procedure required for planning was done, the CT images of the patients and the MRI (Magnetic Resonance Image) that were present in the hospital or brought by the patient outside the hospital were fused and used if deemed necessary by the relevant doctor. GTV, CTV, PTV, OAR and PRV volumes were created in figure 1 . Plans have been made so that $100 \%$ of the dose defined for the target volume will take at least $95 \%$ of the target volume.

The target volume and critical organ doses of the different plans studied using the obtained dose-volume histograms were evaluated using the Radiation Therapy Oncology Group (RTOG) protocol. The organs with contoured OAR were the brainstem, spinal cord, right and left optic nerves, optic chiasma, retinas, lenses and normal brain (except PTV). Evaluation of treatment plans A comparative dosimetric analysis was performed using 10 CT images. In table 1 , at least $100 \%$ coverage of PTV was achieved with $95 \%$ isodose of 60 Gy in 30 fractions without violating the OAR maximum dose restrictions.

Table 1. Recommended tolerance doses for organs at risk.

\begin{tabular}{ll}
\hline Organ at Risk & Dose \\
\hline Brainstem & Maximum dose $<54$ Gy \\
Spinal cord & Maximum dose $<45-50 \mathrm{~Gy}$ \\
Optic nerves & Maximum dose $<54 \mathrm{~Gy}$ \\
Chiasma & Maximum dose $<54 \mathrm{~Gy}$ \\
Retina & Mean dose $<45 \mathrm{~Gy}$ \\
\hline
\end{tabular}

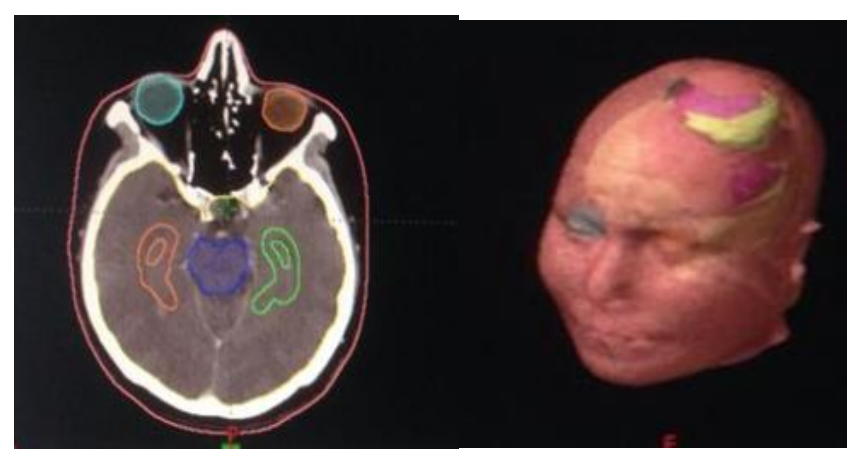

Fig. 1. 3D and transverse representation of the PTV and OAR volumes used in planning.

During the treatment, set-up accuracy is checked regularly with both $\mathrm{kV}$ and MV image guided RT techniques. In this way, by ensuring adequate set-up security, the safety margins for PTV can be reduced and risky organs can be protected.

\section{Results and Discussion}

When the isodose distributions in the axial section of the plans obtained with IMRT and VMAT techniques are examined in figure 2, the dosimetric comparison of the average values of the data obtained from the treatment planning system is shown in table 2. comparing the plan results of 10 patients using IMRT and VMAT techniques according to statistical test results,
While PTV mean IMRT was $60.08 \pm 0.92$ (Gy), PTV mean VMAT was found to be $59.78 \pm 3.19$ and there is no significant difference since it is $\mathrm{p}=(0.787)$.

While PTV max. IMRT was $64.24 \pm 0.812$ (Gy), PTV max. VMAT was found to be $64.835 \pm 0.504$ and there is a significant difference since $\mathrm{p}=(0.039)$.

While PTV min. IMRT was $48.09 \pm 3.19$ (Gy), PTV min. VMAT was found to be $47.75 \pm 5.42$, and there is no significant difference since $\mathrm{p}=(0.768)$.

While Brain max. IMRT is $63.24 \pm 1.529$ (Gy), Brain max. VMAT was found to be $64.378 \pm 0.565$, and there is a significant difference since $\mathrm{p}=(0.025)$.

Brain mean when IMRT is $28.73 \pm 4.73$ (Gy), Brain mean VMAT was found to be $26.74 \pm 3.42$, and there is no significant difference since $\mathrm{p}=(0.096)$.

Brainstem max. While IMRT is $34.17 \pm 20.47$ (Gy) Brainstem max. VMAT was found to be $32.44 \pm 18.70$ and there is no significant difference since $\mathrm{p}=(0.178)$.

Lens L. max. when IMRT is $5.48 \pm 2.635$ (Gy), Lens L. max. VMAT was found to be $6.45 \pm 2.268$, and there is no significant difference since $\mathrm{p}=(0.158)$.

Lens R. max. when IMRT is $6.14 \pm 3.23$ (Gy), Lens R. max. VMAT was found to be $6.28 \pm 2.38$, and there is no significant difference since $\mathrm{p}=(0.881)$.

Eye L. max. while IMRT was $28.61 \pm 15.01$ (Gy), Eye L. max VMAT was found to be $20.39 \pm 12.17$ and there is a significant difference since $\mathrm{p}=(0.046)$.

Eye R. max. while IMRT was $37.69 \pm 14.37$ (Gy), Eye R. max VMAT was found to be $32.90 \pm 16.84$ and there was no significant difference since $\mathrm{p}=(0.076)$.

Optic Nerve L. max. IMRT was found to be $24.21 \pm 14.35$ (Gy), while Optic Nerve L. max VMAT was found to be $23.17 \pm$ 15.45 and there was no significant difference since it was $\mathrm{p}=$ (0.851).

Optic Nerve R. max IMRT was found to be $24.21 \pm 14.35$ (Gy), while Optic Nerve R. max VMAT was found to be $23.17 \pm$ 15.45 and there was no significant difference since $p=(0.851)$.

Optic Chiasma max IMRT was found to be $28.03 \pm 19.69$ (Gy), while Optic Chiasma max VMAT was found to be $25.25 \pm$ $20.24 \mathrm{p}=(0.531)$, so there was no significant difference.

Minitab program was used in statistical calculations. Since the data included in the study were found to be suitable for normal distribution, they were analyzed using the Paired T test.

$\mu \_$difference: mean of (IMRT-VMAT)

$$
\begin{aligned}
& \mathrm{H}_{0}: \mu \_ \text {difference }=0 \\
& \mathrm{H}_{1}: \mu \_ \text {difference } \neq 0
\end{aligned}
$$



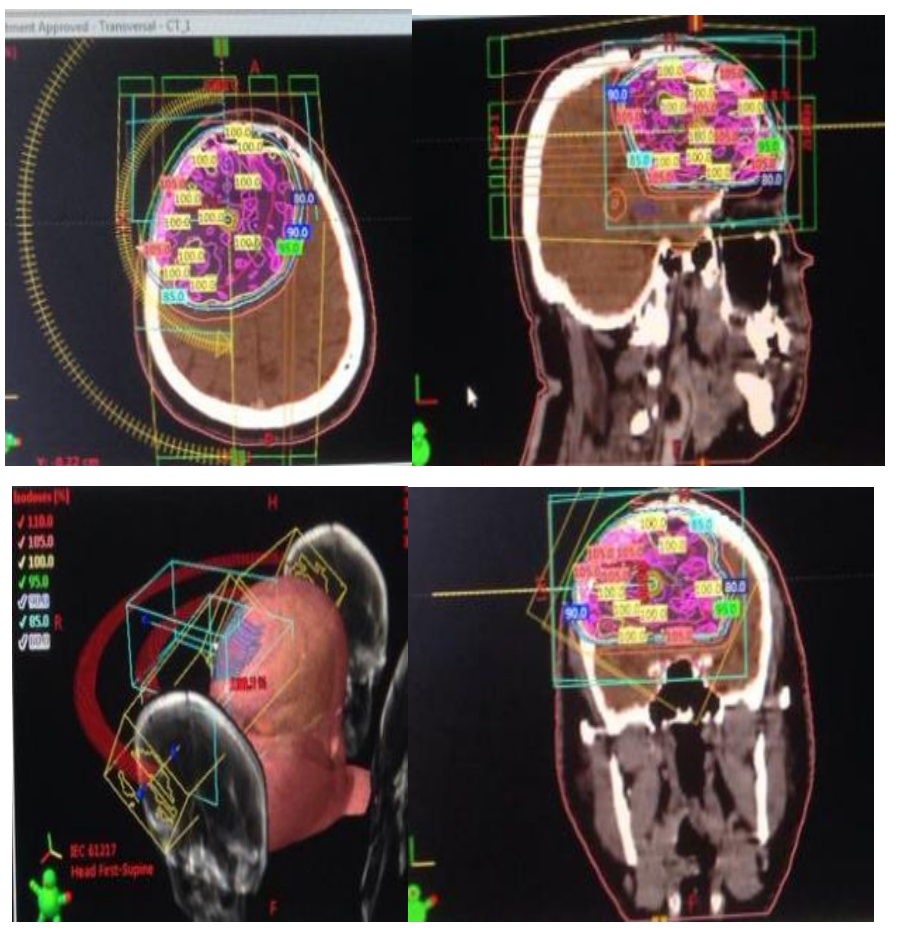

Fig. 2. Axial, sagittal, frontal isodose maps representation of

the dose distribution in PTV in VMAT planning technique.

Table 2: Dosimetric comparison of the mean values of the data obtained with IMRT and VMAT techniques.

\begin{tabular}{lcc}
\hline Variable & $\begin{array}{c}\text { IMRT Mean } \\
\text { (Gy) }\end{array}$ & VMAT Mean (Gy) \\
\hline PTV Mean & $60,08 \pm 0,92$ & $59,78 \pm 3,19$ \\
\hline PTV Max & $64,24 \pm 0,812$ & $64,835 \pm 0,504$ \\
\hline PTV Min & $48,09 \pm 3,19$ & $47,75 \pm 5,42$ \\
\hline Brain Max. & $63,24 \pm 1,529$ & $64,378 \pm 0,565$ \\
\hline Brain Mean & $28,73 \pm 4,73$ & $26,74 \pm 3,42$ \\
\hline Brainstem Max & $34,17 \pm 20,47$ & $32,44 \pm 18,70$ \\
\hline Lens L. Max & $5,48 \pm 2,635$ & $6,45 \pm 2,268$ \\
\hline Lens R. Max & $6,14 \pm 3,23$ & $6,28 \pm 2,38$ \\
\hline Eye L. Max & $28,61 \pm 15,01$ & $20,39 \pm 12,17$ \\
\hline Eye R. Max & $37,69 \pm 14,37$ & $32,90 \pm 16,84$ \\
\hline Optik Nerve L Max & $24,21 \pm 14,35$ & $23,17 \pm 15,45$ \\
\hline Optic Nerve R Max & $23,11 \pm 16,61$ & $22,63 \pm 17,98$ \\
\hline Optic Chiasm Max & $28,03 \pm 19,69$ & $25,25 \pm 20,24$ \\
\hline
\end{tabular}

When the isodose distributions of IMRT and VMAT plans were examined in axial section, both methods provided $100 \%$ isodose coverage for at least $95 \%$ of PTV for all plans. PTV coverage, conformity and homogeneity index were equivalent for VMAT and IMRT plans. Compared to the VMAT plans IMRT, PTV Max, Brain max, and Eye L. max. The difference between the mean doses is statistically significant.

Brain Mean, Brain Stem Max., Eye R. Max, Optic Nerve L Max, Optic Nerve R Max, Optic Chiasma Max were found lower in VMAT plans but were not statistically significant. In the plans made with the VMAT technique, fewer monitor units (MU) and shorter treatment time were obtained.
In the study performed by Shaffer et al. (2010), 95\% isodose coverage was provided to at least $98 \%$ of PTV in all plans made using IMRT and VMAT techniques. Conformality and homogeneity index and the PTV coverage were equivalent with two plans. The IMRT plan failed to meet dose restrictions for the lens. When comparing VMAT with IMRT plan, mean doses given to retinas, lenses and optic nerves were found to be $5-29 \%$ lower. Mean doses of brainstem and chiasma are equivalent. Normal brain mean dose is significantly higher (12\%). Maximum dose values for the brainstem, chiasma, ipsilateral optic nerve, and normal brain were equivalent, and the maximum doses for the contralateral optic nerve, lenses, and retinas were significantly lower, 16-33\%. In the study, the mean MU value for IMRT was $789 \pm 112$, while the mean MU value for VMAT was $363 \pm 45$ and significantly lower. $(54 \% ; \mathrm{p}=0.002)$. The average time to deliver a 2 Gy fraction is $5.1 \pm 0.4$ min with IMRT and $1.8 \pm 0.1$ with VMAT. The mean duration was significantly lower with VMAT plans $(65 \% ; \mathrm{p}=0.002)$.

A planning study comparing 3D-CRT, IMRT, and VMAT for prostate cancer Palma et al. (2008), and studies comparing IMRT and VMAT for head and neck Vanetti et al. (2008), prostate KjaerKristoffersen et al. (2008), and cervical cancers Cozzi et al. (2008), have been published. Similar to our study, while VMAT requires less MU, treatment times for VMAT were 70-90 seconds. Treatment times with IMRT are 5 minutes Kjaer-Kristoffersen et al. (2008), for prostate cancer and 15 minutes Vanetti et al. (2008), for head and neck cancer. The results we found in our study were found to be compatible with the literature.

\section{Conclusions}

IR bolHe and skull base radiotherapy, preserving the patient's quality of life as well as tumor control is of great importance. The fact thet 7 the brain sub-regions involved in cognitive functions in craniab,omation are within the treatment area and the radiation tolerance doses are low are the most important factors determining the quality of life.

The 024 fects of radiation on cognitive functions determine the quality $0,96 \mathrm{dife}$ of our patients. Especially in the treatment of brain tumors, a guality life is as important as living for a long time. Radiation can cause impairment of functions such as thought, memo@y, 580 ncentration and speech and decrease the quality of life. Th,gfollerance doses of critical organs and tissues should not be exceeded.

During treatment planning, selection of ap propriate angles where0 energy and risky organs can be protected maximum, determination of area size and shape, and tolerance doses of RAO' $s$ around are issues to be considered. It should always be kept in mind $9 \mathrm{~s} 6 \$$ preferable treatment method in plans made with the VMAD, (MU) and shorter treatment time.

\section{Acknowledge}

Our work has been done within the framework of academic ethical principles and the ethics committee permission has been obtained under the number 2450 .

\section{References}

Noone, AM, Howlader, N, Krapcho, M, Miller, D, Brest, A, Yu, M, Ruhl, J, Tatalovich, Z, Mariotto, A, Lewis, DR, Chen, HS, Feuer, EJ and Cronin, KA (2015). SEER Cancer Statistics Review, 1975-2015. National Cancer Institute. 
Louis, DN, Perry, A, Reifenberger, G, Von Deimling, A, FigarellaBranger, D, Cavenee, WK, Ohgaki, H, Wiestler, OD, Kleihues, P and Ellison, DW (2016). The 2016 World Health Organization Classification of Tumors of the Central Nervous System: a summary. Acta Neuropathologica, 131 (6), 803820. Doi: $10.1007 / \mathrm{s} 00401-016-1545-1$

Kleihues, P and Cavenee, WK. (2000). Pathology and Genetics of Tumours of the Nervous System. World Health Organization Classification of Tumours. International Agency for Research on Cancer (IARC). IARC Pres, Lyon, 55- 69.

Lyman, JT. (1985). Complication probability as assessed from dosevolume histograms. Radiation Resarch Suppl. 8, 13-19. Doi: $10.2307 / 3583506$

Meral, R. (2007). Radyasyonun Bilissel Fonksiyonlara Etkisi. Türk Nörosirürji Dergisi, 17(3), 139-148.

Çetingöz, R. (2015). Radyoterapi Teknikerlerinin Görev ve Sorumlulukları (p. 5-7). Türk Radyasyon Onkolojisi Derneği Temel ve Klinik Radyoterapi. ISBN:978-605-63913-0-9.

.Gunderson, LL, Tepper, JE. (2008). Clinical Radiation Oncology (5th edition). Elsevier \& Saunders, Philadephia. Hardcover ISBN: 9780323672467.

Komaki, R, Meyers, CA, Shin, DM, Garden, AS, Byrne, K, Nickens, JA and Cox JD (1995). Evaluation of cognitive function in patients with limited small cell lung cancer prior to and shortly following prophylactic cranial irradiation. International Journal Radiation Oncology Biol. Phys. 33(1), 179-182. DOI: $\underline{10.1016 / 0360-3016(95) 00026-U}$

Narayana, A, Yamada J and Berry S (2006). Intensity-modulated radiotherapy in high-grade gliomas: Clinical and dosimetric results. Int. J. Radiat Oncol Biol Phys 64, 892-897 DOI: $10.1016 /$ j.ijrobp.2005.05.067.

Thilmann C, Zabel A, Grosser KH, Hoess A, Wannenmacher M and Debus J (2001). Intensity-modulated radiotherapy with an integrated boost to the macroscopic tumor volume in the treatment of high-grade gliomas. International Journal Cancer, 96:341-349. DOI: 10.1002/ijc.1042.

Floyd, NS, Woo, SY, Teh, BS, Prado, C, Mai, YW, Trask, T, Gildenberg, PL, Holoye, P, Augspurger, ME, Carpenter, SL, Lu, HH, Chiu, KJ, Grand, WH and Butler, EB (2004). Hypofractionated intensitymodulated radiotherapy for primary glioblastoma multiforme. International Journal
Radiation Oncol. Biol. Phys. 58:721-726. DOI: $10.1016 / \mathrm{S} 0360-3016(03) 01623-7$

Miwa, K, Matsuo, M, Shinoda, J, Oka, N, Kato, T, Okumura, A, Ueda, T, Yokoyama, K, Yamada, J, Yano, H, Yoshimura, S and Iwama, $\mathrm{T}$ (2008). Simultaneous integrated boost technique by helical tomotherapy for the treatment of glioblastoma multiforme with 11C-methionine PET: Report of three cases. J Neuro Oncol. 87(3), 333-339. DOI: $10.1007 / \mathrm{s} 11060-008-9519-3$.

Yu, CX. (1995). Intensity-modulated arc therapy with dynamic multileaf collimation: An alternative to tomotherapy. Phys Med. Biol. 40(9) 1435-1449. DOI: 10.1088/00319155/40/9/004.

Otto, K. (2008). Volumetric modulated arc therapy: IMRT in a single gantry arc. Med. Phys 35:310-317. DOI: $10.1118 / 1.2818738$

Shaffer R, Alan M, Nichol MD, Vollans E, Fong M, Nakano S, Moiseenko V, Schmuland M, Mickenzie M and Otto $\mathrm{K}$ (2010). A Comparıson of Volumetric Modulated Arc Therapy And Conventional Intensity-Modulated Radiotherapy For Frontal And Temporal High-Grade Gliomas. Int. J. Radiation Oncology Biol. Phys 76(4), 1177-1184. DOI: 10.1016/j.ijrobp.2009.03.013

Palma D, Vollans E, James K (2008). Volumetric modulated arc therapy for delivery of prostate radiotherapy: Comparison with intensity-modulated radiotherapy and three-dimensional conformal radiotherapy. Int J Radiat Oncol Biol Phys,72: 996-1001.

Vanetti E, Clivio A, Nicolini G, (2008). Volumetric modulated arc radiotherapy for carcinomas of the oro-pharynx, hypopharynx and larynx: A treatment planning comparison with fixed field IMRT. Radiother Oncology.

Kjaer-Kristoffersen F, Ohlhues L, Medin J (2008). RapidArc volumetric modulated therapy planning for prostate cancer patients. Acta Oncology, 48:227-232.

Cozzi L, Dinshaw KA, Shrivastava SK (2008). A treatment planning study comparing volumetric arc modulation with Rapid Arc and fixed field IMRT for cervix uteri radiotherapy. Radiother Oncology, 89:180-191. 